\title{
The Importance of Science, Technology and Innovation in the Green Growth and Sustainable Development Goals of Colombia
}

\author{
Clara Inés PARDO MARTÍNEZ ${ }^{*}$, Alexander COTTE POVEDA ${ }^{2}$ \\ ${ }^{1}$ School of Administration, Universidad del Rosario, Calle 12C No. 6-25 Bogotá, Colombia \\ ${ }^{2}$ Department of Economics, Universidad Santo Tomas, Carrera 9 No. 51-11 Bogotá, Colombia
}

\begin{abstract}
Green growth and sustainable development goals (SDGs) are two strategies to improve the productivity and competitiveness of countries with respect to environmental protection. In these strategies, science, technology and innovation (STI) plays an important role in generating new knowledge. Colombia is a highly diversified country that is currently seeking to promote green growth initiatives and the SDGs through five axes: policy, new economic opportunities from the sustainable use of natural resources, the efficient use of natural capital and energy in production, business and human competences and capacities in STI. In this context, this study seeks to analyse the main contributions and adequate measures that determine the relationships between green growth, SDGs and STI in Colombia over recent years using different econometric models. The results of this study suggest the importance of STI in promoting green growth and achieving SDGs. In other words, higher investments in STI promote lower pollution and higher productivity, competitiveness and development, and new knowledge and technologies are found to be important to increasing the sustainable use of natural resources in productive processes. These results suggest policy implications with regard to energy use and conservation, resource efficiency, and the reduction of pollution. It is important to formulate and frequently measure the indicators of STI related to green growth and SDGs from a baseline, as this will allow us to analyse improvements in competitiveness and productivity from a sustainable development perspective.
\end{abstract}

Keywords - Colombia; empirical analysis; green growth; science, technology and innovation; sustainable development goals

\section{INTRODUCTION}

Worldwide, there is a general consensus that growth has been achieved at the expense of natural resources and the environment. The subsequent environmental degradation affects human activities, especially the population living in poverty, through extreme and violent weather, floods and climate change. Different interest groups, such as policymakers, development experts, decision-makers and international organizations (the World Bank, the Interamerican Development Bank, etc.), have developed effective strategies for ending poverty, generating economic growth, making demand inclusive and sustainable and achieving fundamental universal access to energy, responsible and conscientious resource use

\footnotetext{
* Corresponding author.

E-mail address: cipmusa@yahoo.com 
and management and good governance [1]. In these strategies, science, technology and innovation (STI) have important roles in improving the quality of life, the production process and the sustainable use of natural resources.

Green growth can reduce poverty, reduce vulnerability to climate change and natural disasters, create economic growth, increase energy security, and provide safer livelihoods for those directly dependent on the utilization of natural resources. In green growth, innovation processes and scientific knowledge are fundamental to achieving the appropriate use of natural assets and resources [2]-[4].

Green growth has a close relationship with sustainable development goals (SDGs) in that it encourages economic growth and development while simultaneously guaranteeing that natural assets continue to deliver the resources and environmental services that are essential to social welfare. To do this, investments in STI and the knowledge generated can guarantee sustained growth that protects the environment and gives rise to new economic and business opportunities, which can help achieve the decoupling of development and economic growth from environmental pressures at the lowest possible cost [5].

In developing countries, an integrated strategy that includes green growth and SDGs can generate multiple benefits that promote the cost-effective and efficient use of resources, leading to sustainable production and consumption choices. However, the following approaches to generating such strategy must be designed and effectively implemented based on the context [6].

Green growth and sustainable development have common elements and interrelationships that can be located within the "here now", "later" and "elsewhere" categories; these categories are respectively transformed into human welfare, capital for different uses and effects on other regions and countries in the measurement framework of green growth and sustainable development [7].

Studies on green growth and sustainable development can be divided in the following manner:

1. The first category includes policies that determine the analytical methods and adequate instruments to promote green growth through resource use and efficiency; the changes and transformations of energy systems; the determination of natural capital and the costs of environmental externalities in national accounting and economic calculations; the connection between social development and pollution control; the design of strategies to apply green growth, benefits, and instruments; and the financial instruments and tools to apply and analyse the effects of green growth [8]-[11];

2. The second category includes the relationship between sustainability and green growth and analyses green product and process innovations, product and process ecoinnovations, environmental management systems, regulations, cost savings, competitive pressures, customer demands, managerial environmental concerns, economic incentives, technological applications, and sources of knowledge and information, among others [12]-[16];

3. The third category involves analysing technology and innovation with respect to their roles in green growth; adequate policy tools to foster green technologies and innovations (benefits, price signals, purchase agreements, and taxation, among other); barriers to dissemination and adaptation technologies, especially in developing countries; technology transfers and absorptive capacity [17]-[21];

4. The fourth category includes the measurements and indicators that are used to assess green growth by empirically analysing the reduction in natural resources, the damage caused by pollution, the value of natural capital, and tax subsidies [22]-[23]. These studies show the importance of green growth in different contexts, how green growth 
allows a country to develop and the challenges for global society.

From these studies, one can conclude that most studies on green growth are relatively recent, since the debate began during the global crisis of 2008. In this context, the main objective of this study is to analyse the main contributions and identify adequate measures to establish the relationship between green growth, SDGs and STI in Colombia; to this end, different econometric models are used to show these relationships and the main contributions of STI towards sustainable development over recent years.

This research contributes to the existing knowledge on the importance of STIs for achieving green growth and SDGs in an emerging economy such as Colombia through the use of empirical analysis. First, it contributes by analysing how green growth and SDGs depend on new knowledge obtained through STI. Second, it contributes by demonstrating the different relationships between STI and green growth using empirical analysis. The remainder of this paper is structured as follows. Section 1 is the introduction, including the study's identified research gap and the aim of the paper. Section 2 describes the literature review, which covers the main trends in green growth and SDGs in Colombia. In Section 3, the study's method is reviewed, including the empirical setting, the sample and data collection, and the measures. In Section 4, the results are presented, discussed and compared with those of the prior literature. Section 6 concludes this study.

\section{Green Growth and Sustainable Development Goals in Colombia}

In 2012, Colombia and 41 other countries signed the declaration of green growth written by the OECD. Green growth works with economic growth trajectories to guarantee the following in the long run: i. economic development (to promote new economic opportunities and increase productivity), ii. Social welfare (to encourage social inclusion, human development and new job opportunities), iii. The conservation of natural capital (to reduce environmental impacts, improve efficiency in resource use and recognize an associated value of natural capital), and iv. Climate security (to promote growth that is compatible with preserving the climate). Achieving these challenges is fundamental to guaranteeing investments in STI.

In Colombia, the green growth policy has a direct effect on the fulfilment of the nine SDGs $(6,7,8,9,11,12,13,14$, and 15) and indirect effects on seven goals $(1,2,3,4,5,10$, and 16). Colombia has the five structural axes of green growth policy in Colombia [24]: i. New economic opportunities from the sustainable use of natural capital; ii. Efficient consumption of natural capital and energy in productive sectors; iii. Business and human capital for green growth; iv. Capacities in STI for green growth; v. Governance for green growth, which seek to promote and enhance the use of natural resources through the bio-economy, forest economy, and green jobs; to increase the productivity of soil and water and energy efficiency; and to apply adequate measurement and monitoring tools to evaluate green growth policy, obtain lessons learned and early warnings, and, with these data, improve the instruments of this policy and achieve sustainable development.

In the Colombian context, it is important to analyse the advantages and possibilities that can be offered by green growth and compliance with SDGs in terms of increased productivity, innovation and competitiveness achieved by accessing the biodiversity and environmental potential that this country possesses; this represents a key strategy for achieving peace and sustainable development.

Environmental performance in Colombia is characterized by Colombia being the world's second most biodiverse country, with forests covering more than half its territory, abundant 
water and improved access to water services, low $\mathrm{CO}_{2}$ emissions from fuel combustion per unit of gross domestic product (GDP) due to heavy reliance on hydropower and the potential to convert resources from well-managed minerals, metals and fossil fuels into infrastructure investment. However, in terms of environmental performance, Colombia has the following challenges: extensive cattle farming, which contributes to land degradation, deforestation and greenhouse gas emissions; poorly regulated extractive industries, damaging human health and the environment; climate change vulnerability, bringing significant economic, environmental and social costs; poor environmental integration within the national policy framework; and wide disparities in income, landholdings and access to environmental services [25], [26]. These issues require an analysis of the relationship between STI and green growth, which is the objective of this study. In general terms, Fig. 1 shows the economic development of the Colombian departments measured by GDP per capita and the deforestation rate for 2018 as a first approach to capturing the relationship between economic development and the deforestation rate. An inverse relationship is shown between the economic development of the different departments and the rate of deforestation, which is explained by fact that the more developed departments see a decreased deforestation rate, and it tends to be negative for the regions and their respective departments.



Fig. 1. Relationship between GDP per capita and deforestation rate for Colombia 2018.

\section{Methods ANd DATA}

\subsection{Method and the generalized method of moments (GMM) estimator}

The generalized method of moments (GMM) is an econometric estimation technique that allows us to interpret the estimates of various proposed models related to economic growth and its various relationships. This procedure allows the development of novel estimation methods, especially those adapted to problems related to economic growth and sustainable development in different countries. One of the most relevant applications of this method is that applied to panel data [27]. 
The proposed models seek to analyse the relationship between green growth and STI through two approaches: the science and technology model (see Eq. 9) and the environmental and energy model (see Eq. 10).

The methods used in this research generate reliable estimates for the unobserved individual effects that affect green growth. These individual effects are generally related to variations in unobserved department-specific and time effects that are associated with heterogeneity across departments and their representative dynamics. We apply an econometric model that is dynamic because the explanatory variable set includes a lag of the dependent variable and some explanatory variables that are potentially jointly endogenous in the sense of being correlated with the error term. To assess these models consistently and efficiently, we apply a GMM estimation for the dynamic panel data models [28], [29] that contains regression equations for the differences and levels, each of which has a specific set of instrumental variables (we use the system GMM estimator) ${ }^{2}$.

The method estimates the simultaneity in the differences and levels of an equation using a specific set of instrumental variables in every regression. The general Eq. (1) of the model is the following:

$$
\psi_{i t}=\gamma \psi_{i, t-1}+\zeta X_{i t}^{\prime}+\eta_{i}+\mathrm{v}_{i t}
$$

where

$\psi_{i t} \quad$ deforestation rate in period $t$ for department $i$;

$\gamma \quad$ lagged coefficient of $\psi$;

$X \quad$ matrix of explicative variables of the model with their respective coefficients $\zeta$;

$\eta \quad$ vector of fixed effects (it does not vary with time) for $i$ departments;

$v \quad$ an i.i.d. random error.

To eliminate the specific effects of every department, Eq. (1) can be expressed by its first differences:

$$
\psi_{i, t}-\psi_{i, t-1}=\gamma\left[\psi_{i, t-1}-\psi_{i, t-2}\right]+\xi\left[X_{i, t}-X_{i, t-1}\right]+\left[v_{i, t}-v_{i, t-1}\right]\left[\text { Since } \eta_{i}-\eta_{i}=0\right]
$$

In this specification, the instrument is selected to resolve the endogeneity problems in the explicative variables by considering that the performance of variables is impacted by the past performance of the dependent variable. Moreover, since residuals are not serially correlated and explicative variables are weakly exogenous.

The difference estimator is based on the GMM estimator. To resolve the problems of low asymptotic and biased precision in small samples, the GMM estimator must be complemented with a multilevel regression equation.

The specific effects of departments are not eliminated directly and must be controlled using instrumental variables. Adequate instruments for the multilevel regression are the lagged differences of the corresponding variables. Although the levels of the explicative variables can be correlated with specific departmental effects, there is no correlation between the differences in these variables and the specific departmental effects. Adequate instruments for a multilevel regression are given by the lagged differences of the system variables.

Using the moment conditions, the GMM provides consistent estimators, and a more efficient GMM estimator is achieved by applying the ponderation matrix that corresponds to the variance-covariance of the moment conditions.

\footnotetext{
${ }^{2}$ The use of instrumental variables is required to resolve the problems of simultaneity and reverse causation generated by the likely endogeneity of the regressors applied in this type of equation and to reduce the estimation bias generated by the underreporting of deforestation areas.
} 
The consistency of the GMM estimator differs based on whether the lagged values of the explicative variables are valid and there are adequate instruments in the regression. To determine these conditions, in this analysis, two tests suggested by [30], [31] are applied. First is the Sargan test of overidentifying restrictions, which can evaluate the general validity of the instruments by analysing the sample analogue of the moment conditions used in the estimation process. The Sargan test is as follows:

$$
S=\left[\sum_{i} \hat{\epsilon}_{2 i}^{\prime} \boldsymbol{Z}_{i}\right] \boldsymbol{A}_{2}\left[\sum_{i} \boldsymbol{Z}_{i} \hat{\epsilon}_{2 i}\right]
$$

The second test examines the hypothesis that the error term $\left(v_{i t}\right)$ is not correlated in the series, thereby determining if the differenced error term (the residual of the difference regression) is correlated in the first- and second-order series.

\subsection{Data}

In this study, we use panel data for the sample period from 2005-2017 for Colombian departments ${ }^{3}$. The dependent variable is the deforestation rate of each department. The data come from the Colombian Department of Statistics (DANE). The investment data related to STI are published by the Colombian Observatory of Science and Technology (OCyT). The patent application data come from the Industry and Commerce Superintendence (SIC). The data on the number of $\mathrm{PhD}$ programmes related to green growth come from the National System of Information of Higher Education. The data on the papers published in earth and environmental sciences are taken from WoS, Scopus, and Scielo. The energy data are published by the Public Utility Superintendence (SSPD) through the SUI system and the Unit of Mines and Energy Planning (UPME). Finally, the related forest data come from the Environmental Studies Institute (IDEAM). In this study, the two models are applied: i. The science and technology model and ii. The environmental and energy model.

\section{RESUlTS AND DisCUSSION}

In this study, the following models are proposed and calculated with the GMM estimator. The science and technology model follows Eq. (4):

$$
\begin{aligned}
& \ln \left(D R_{i t}\right)=\alpha+\beta \ln \left(D R_{i t-1}\right)-v \ln \left(R \& D_{i t}\right)-\gamma \ln \left(E D U_{i t}\right)- \\
& \phi \ln \left(M G_{i t}\right)-\sigma \ln \left(P A T_{i t}\right)-\lambda \ln \left(P h D_{i t}\right)-\xi \ln \left(P P_{i t}\right)+\eta_{i}+v_{i t} .
\end{aligned}
$$

Note that $D R_{i t}$ is the deforestation rate in period $t$ for department $I, D R_{i t-1}$ is the lagged coefficient of the deforestation rate, $R \& D_{i t}$ is the investments in research and development by department, $E D U_{i t}$ is the investments in science and technology education by department, $M G_{i t}$ is the investments related to science and technology management by department, $P A T_{i t}$ is the patent applications by department, $P h D_{i t}$ is the number of $\mathrm{PhD}$ programmes related to green growth by department, and $P P_{i t}$ is the number of papers published in environmental science in period t by the department. The environmental and energy model follows Eq. (5):

$$
\begin{aligned}
& \ln \left(D R_{i t}\right)=\alpha+\beta \ln \left(D R_{i t-1}\right)-v \ln \left(R \& D_{i t}\right)-\gamma \ln \left(E D U_{i t}\right)-\phi \ln \left(M G_{i t}\right)-\Psi \ln \left(P A T_{i t}\right)-\sigma \ln \left(E L E_{i t}\right)+ \\
& \lambda \ln \left(N G_{i t}\right)+\xi \ln \left(E N E_{i t}\right)+\zeta \ln \left(C O_{i t}\right)-\Pi \ln \left(C C_{i t}\right)+\vartheta \ln \left(R A_{i t}\right)+\omega \ln \left(S F_{i t}\right)+\eta_{i}+v_{i t .}
\end{aligned}
$$

\footnotetext{
${ }^{3}$ Departments are sub-national political territories in Colombia.
} 
Note that $D R_{i t}$ is the deforestation rate in period $t$ for department $i, D R_{i t-1}$ is the lagged coefficient of the deforestation rate, $R \& D_{i t}$ is the investment in research and development by department, $E D U_{i t}$ is the investments in science and technology education by department, $M G_{i t}$ is the investments related to science and technology management by department, $E L E_{i t}$ is the electricity consumption by department, $N G_{i t}$ is the natural gas consumption by department, $E N E_{i t}$ is total energy consumption in period t by department, $C O_{i t}$ is the total emissions of carbon dioxide by department, $C C_{i t}$ is the changes in surfaces covered by natural forces, $R A_{i t}$ is the regenerated area by department, and $S F_{i t}$ is the stable forest area by department.

Table 1 and Table 2 show the results of the regression models using a dynamic panel model for green growth measured as the deforestation rate by department for the science and technology model (Eq. 4 and Table 2) and the environmental and energy model (Eq. 5 and Table 3), determining the key variables in the relationship of STI and green growth, as explained in this section. The tests applied in both models indicate that the results are robust because the Sargan test of overidentifying restrictions does not reject the null hypothesis that the instruments are not correlated with the error process. In both models, the results for the lagged deforestation rate show a positive and significant effect on deforestation rates, thus indicating that deforestation can be explained over time by different events.

TABLE 1. RESUlts FOR THE SCIENCE AND TECHNOLOGY MODEL

\begin{tabular}{|c|c|c|c|c|}
\hline Parameter & [1] & [2] & [3] & [4] \\
\hline Constant & $-0.088^{\mathrm{a}}(0.002)$ & $-0.088^{\mathrm{a}}(0.002)$ & $-0.088^{\mathrm{a}}(0.001)$ & $-0.082^{\mathrm{a}}(0.001)$ \\
\hline $\begin{array}{l}\text { Lagged } \\
\text { deforestation rate }\end{array}$ & $0.783^{\mathrm{a}}(0.000)$ & $0.783^{\mathrm{a}}(0.000)$ & $0.784^{\mathrm{a}}(0.000)$ & $0.786^{\mathrm{a}}(0.000)$ \\
\hline Investments in $R \& D$ & $-6.03 \mathrm{e}^{-06 \mathrm{a}}\left(1.15 \mathrm{e}^{-07}\right)$ & $-5.97 \mathrm{e}^{-06 \mathrm{a}}\left(9.64 \mathrm{e}^{-08}\right)$ & $-6.02 \mathrm{e}^{-06 \mathrm{a}}\left(2.34 \mathrm{e}^{-07}\right)$ & $-5.58 \mathrm{e}^{-06 \mathrm{a}}\left(1.56 \mathrm{e}^{-07}\right)$ \\
\hline $\begin{array}{l}\text { Investments in STI } \\
\text { education }\end{array}$ & $-0.000^{\mathrm{a}}(0.000)$ & $-0.000^{\mathrm{a}}(0.000)$ & $-0.000^{\mathrm{a}}(0.000)$ & $-0.000^{\mathrm{a}}(0.000)$ \\
\hline $\begin{array}{l}\text { Investments in STI } \\
\text { management }\end{array}$ & - & $-2.67 \mathrm{e}^{-06 \mathrm{a}}\left(4.27 \mathrm{e}^{-07}\right)$ & $-3.15 \mathrm{e}^{-06 \mathrm{a}}\left(5.32 \mathrm{e}^{-07}\right)$ & $-2.91 \mathrm{e}^{-06 \mathrm{a}}\left(3.22 \mathrm{e}^{-07}\right)$ \\
\hline Patent applications & - & - & $-0.000^{\mathrm{a}}\left(9.76 \mathrm{e}^{-06}\right)$ & $-0.000^{\mathrm{a}}\left(9.42 \mathrm{e}^{-06}\right)$ \\
\hline $\begin{array}{l}\text { Number of } \mathrm{PhD} \\
\text { programmes }\end{array}$ & - & - & - & $-0.000^{\mathrm{a}}(0.000)$ \\
\hline $\begin{array}{l}\text { Papers published on } \\
\text { environmental } \\
\text { topics }\end{array}$ & - & - & - & $-0.000(0.000)$ \\
\hline Sargan test (P value) & 0.163 & 0.164 & 0.165 & 0.191 \\
\hline Serial correlation & & - & - & - \\
\hline First-order & 0.0092 & 0.0093 & 0.0090 & 0.0095 \\
\hline Second-order & 0.9864 & 0.9952 & 0.3973 & 0.7782 \\
\hline No. of obs & 363 & 363 & 363 & 363 \\
\hline
\end{tabular}

Notes: Figures in parentheses are the standard errors: ${ }^{a}$ Significant at the 10 percent level, ${ }^{\mathrm{b}}$ Significant at the 5 percent level and ${ }^{\mathrm{c}}$ Significant at the 1 percent level.

Green growth implies enhancing economic growth and development while guaranteeing that natural assets (as forest resources) continue to deliver the resources and environmental services on which wellbeing relies [31]. For example, the forestry sector is the largest producer of biomass [32], which is an important input for green growth when forest exploitation is equitable, considering the fact that natural assets not infinitely substitutable and green growth policies. In this context, this study uses the deforestation rate as the 
dependent variable because it allows an analysis of the impossibility of green growth given a higher deforestation rate and the variables that could decrease the rate of deforestation and contribute to green growth through STI and environmental and energy performance.In general, green growth has a close relationship with the trends in the environmental and energy variables. For green growth, it is important to promote adequate policies to protect natural resources, and it is necessary to transform the energy sector throughout the value chain through governmental actions on two levels: in the short term, by promoting energy efficiency and savings using different technical and behavioural measures, and in the long term, by improving the infrastructure to use less energy and guarantee better social and economic results [33]. Green growth strategies seek natural assets that can promote economic growth based on sustainable development, which include providing critical life support services, maintaining air and water quality, and protecting resilient biodiversity to guarantee food security and human health through adequate policies that take into account that natural assets are not infinitely substitutable [34].

The first model, which is named the science and technology model (see Table 1), indicates the factors that affect green growth, as measured by the deforestation rate across Colombian departments, after investments in R\&D, STI education and STI management. These have negative signs and significant effects on green growth, thus indicating that higher investments related to science and technology generate lower deforestation rates and suggesting that it is important for the public and private sector to increase investment to promote green growth based on STI. These results show that the deforestation rate decreases because R\&D investments generate higher innovation, which could influence the use of alternative materials with lower environmental impacts with respect to forest products. These investments include STI education and investments in STI management, which concurs with [35], who demonstrated the existence of a nexus between STEAM careers and topics related to energy, the bio-economy, climate change and the environment.

Patent applications and papers published on environmental topics likely have a negative effect on deforestation, indicating that STI results are important in green growth because they generate new knowledge to process and achieve the rational use of natural resources as a key element of green growth. This connection, in part, occurs because new knowledge leads to a higher awareness of the need to protect the environment and develop cleaner processes.

This model indicates the importance of investments in R\&D, STI education and STI management in promoting and achieving green growth. Decreasing poverty and increasing economic growth and environmental sustainability require scientific knowledge, the development of new green technologies and innovation processes, especially in emerging economies where STI is limited, which concurs with [18]. To support STI in green processes and activities, policy instruments could determine R\&D subsidies and carbon taxes, promote the application of new green technologies, foster better connections between research institutions and industries and establish multiple benefits from green growth based on STI to achieve better development [36].

Patent applications and scientific production had an inverse relationship with the deforestation rate, indicating that knowledge production is the basis for achieving green growth. Green patents are a tangible result. They promote environmental protection, can help promote STI and cleaner processes in eco-friendly businesses, and increase profit margins in companies through environmental protection, sustainable development and green growth. These findings demonstrate the importance of integrating production knowledge from basic science to applied research, especially in developing countries, which must promote research and development according to regional requirements. The aim is to value natural capital (biodiversity and ecosystem services); assess how natural capital accounting can address 
capital substitution and support sustainability; and design new indicators to analyse green growth and measure policy interventions and their impacts to promote green skills, taxes and subsidy reforms related to the environment. It is necessary to standardize the measurement and reporting metrics that allow one to monitor the progress and effects of STI on green growth and sustainable development [37].

The second model, which is named the environmental and energy model (see Table 2), shows that energy and forest management variables are important to decreasing the deforestation rate and promoting green growth across Colombian departments. Energy consumption has a positive sign and significant effect on the deforestation rate, indicating that higher energy consumption results in a higher deforestation rate, which can be explained by the construction of new energy projects that require large deforested areas or the exploitation of land to obtain energy resources. Another problem in Colombia is illegal crops and mining, which increase the deforestation rate, in some cases to provide energy sources. This finding is aligned with the results of [38] for the Colombian context.

It is important to analyse strategies for promoting energy efficiency and cleaner energy sources to promote green growth and sustainable development. The same trend is given using carbon dioxide emissions. In the case of the forest variables, the results indicate that actions related to forest protection and natural resources are important for stabilizing and protecting natural resources in the framework of green growth.

Green growth has a close relationship with energy, thus indicating that higher energy consumption affects sustainable development. It is important for any analysis to consider the following four points [39], [40].

1. Energy innovation from technological change and the alignment processes from basic research affect the commercialization of technologies that aim to transform energy use and consumption by considering regional features and possible energy sources that allow for the transformation of energy systems according to the requirements of green growth.

2. Energy integration through new technologies benefits the market if supported by the formulation of policies that ensure transparency and quality, especially in the initial stages of diffusion.

3. Energy implementation requires that the policies that promote clean technologies through minimum standards, labelling, energy performance indicators and other regulatory incentives can help transform current technologies into more prevalent uses.

4. Energy transformations imply adequate policies that assess clean energy and different incentives to transform energy systems in the pursuit of green growth and sustainable development.

In the case of carbon dioxide emissions, green growth allows one to strengthen the decoupling between growth and carbon dioxide emissions. Here, it is recognized that it is possible to reduce carbon emissions by applying green growth and sustainable agendas, but these require a combined strategy that changes investment patterns and transitions in the use of natural resources [41], [42], which concurs with the results of this study.

Forest protection is fundamental to achieving green growth, as indicated by the results of the model, because it strengthens a carbon cycle economy that highlights renewable forest resources, the conservation and management of forest resources, the improvement in the quality of a "green life", the sharing of experiences and contributions to the international dialogue through a transition to a green economy. These effects occur through long-term investments in the forest sector and the comprehensive implementation of forest policies that reflect changes over time in countries [43]. 
TABLE 2. RESUlTS FOR THE ENVIRONMENTAL AND ENERGY MODEL

\begin{tabular}{|c|c|c|c|c|c|}
\hline Parameter & 1 & 2 & 3 & 4 & 5 \\
\hline Constant & $-0.084^{\mathrm{a}}(0.001)$ & $-0.084^{\mathrm{a}}(0.001)$ & $-0.085^{\mathrm{a}}(0.001)$ & $-0.088^{\mathrm{a}}(0.001)$ & $\begin{array}{l}-0.139 \\
\mathrm{a}(0.004)\end{array}$ \\
\hline $\begin{array}{l}\text { Lagged } \\
\text { deforestation } \\
\text { rate }\end{array}$ & $0.784^{\mathrm{a}}(0.000)$ & $0.784^{\mathrm{a}}(0.000)$ & $0.784^{\mathrm{a}}(0.000)$ & $0.784^{\mathrm{a}}(0.000)$ & $\begin{array}{l}0.842 \\
\mathrm{a}(0.000)\end{array}$ \\
\hline $\begin{array}{l}\text { Investments } \\
\text { in R\&D }\end{array}$ & $\begin{array}{l}-6.13 \mathrm{e}^{-06 \mathrm{a}} \\
\left(2.81 \mathrm{e}^{-07}\right)\end{array}$ & $\begin{array}{l}-6.15 \mathrm{e}^{-06 a} \\
\left(2.76 \mathrm{e}^{-07}\right)\end{array}$ & $\begin{array}{l}-5.99 \mathrm{e}^{-06 \mathrm{a}} \\
\left(2.61 \mathrm{e}^{-07}\right)\end{array}$ & $\begin{array}{l}-6.01 \mathrm{e}^{-06 \mathrm{a}} \\
\left(2.22 \mathrm{e}^{-07}\right)\end{array}$ & - \\
\hline $\begin{array}{l}\text { Investments } \\
\text { in STI } \\
\text { education }\end{array}$ & $-0.000^{\mathrm{a}}(0.000)$ & $-0.000^{\mathrm{a}}(0.000)$ & $-0.000^{\mathrm{a}}(0.000)$ & $-0.000^{\mathrm{a}}(0.000)$ & - \\
\hline $\begin{array}{l}\text { Investments } \\
\text { in STI } \\
\text { management }\end{array}$ & $\begin{array}{l}-2.83 \mathrm{e}^{-06 a} \\
\left(7.27 \mathrm{e}^{-03}\right)\end{array}$ & $\begin{array}{l}-2.98 \mathrm{e}^{-06 \mathrm{a}} \\
\left(7.48 \mathrm{e}^{-07}\right)\end{array}$ & $\begin{array}{l}-2.45 \mathrm{e}^{-06 \mathrm{a}} \\
\left(3.98 \mathrm{e}^{-07}\right)\end{array}$ & $\begin{array}{l}-3.18 \mathrm{e}^{-06 \mathrm{a}} \\
\left(6.16 \mathrm{e}^{-07}\right)\end{array}$ & - \\
\hline $\begin{array}{l}\text { Patent } \\
\text { applications }\end{array}$ & $-0.000^{\mathrm{a}}(0.000)$ & $-0.000^{\mathrm{a}}(0.000)$ & $-0.000^{\mathrm{a}}(0.000)$ & $\begin{array}{l}-0.000^{\mathrm{a}} \\
\left(9.98 \mathrm{e}^{-06}\right)\end{array}$ & - \\
\hline $\begin{array}{l}\text { Electricity } \\
\text { consumption }\end{array}$ & $-0.000^{\mathrm{a}}(0.000)$ & $-0.000^{\mathrm{a}}(0.000)$ & $-0.001^{\mathrm{a}}(0.000)$ & - & - \\
\hline $\begin{array}{l}\text { Natural gas } \\
\text { consumption }\end{array}$ & - & $\begin{array}{r}3.16 \mathrm{e}^{-06 \mathrm{a}} \\
\left(1.13 \mathrm{e}^{-06}\right)\end{array}$ & $\begin{array}{l}1.64 \mathrm{e}^{-06} \\
\left(1.15 \mathrm{e}^{-06}\right)\end{array}$ & - & - \\
\hline $\begin{array}{l}\text { Total energy } \\
\text { consumption }\end{array}$ & - & - & $0.001^{\mathrm{a}}(0.000)$ & - & - \\
\hline $\begin{array}{l}\mathrm{CO}_{2} \\
\text { emissions } \\
\text { from natural } \\
\text { gas }\end{array}$ & - & - & - & $\begin{array}{l}2.75 \mathrm{e}^{-06 \mathrm{c}} \\
\left(1.25 \mathrm{e}^{-06}\right)\end{array}$ & - \\
\hline $\begin{array}{l}\text { Change in } \\
\text { natural } \\
\text { surface cover }\end{array}$ & - & - & - & - & $\begin{array}{l}-0.010 \\
\mathrm{a}(0.000)\end{array}$ \\
\hline $\begin{array}{l}\text { Regenerated } \\
\text { area }\end{array}$ & - & - & - & - & $\begin{array}{l}0.000 \\
\mathrm{a}(0.000)\end{array}$ \\
\hline $\begin{array}{l}\text { Stable forest } \\
\text { area }\end{array}$ & - & - & - & - & $\begin{array}{l}0.007 \\
\mathrm{a}(0.001)\end{array}$ \\
\hline $\begin{array}{l}\text { Sargan test }(\mathrm{P} \\
\text { value) }\end{array}$ & 0.206 & 0.217 & 0.226 & 0.164 & 0.250 \\
\hline $\begin{array}{l}\text { Serial } \\
\text { correlation }\end{array}$ & - & - & - & - & - \\
\hline First-order & 0.0090 & 0.0090 & 0.0089 & 0.0090 & 0.0074 \\
\hline Second-order & 0.3866 & 0.3872 & 0.4310 & 0.3970 & 0.8496 \\
\hline No. Obs & 363 & 363 & 363 & 363 & 363 \\
\hline
\end{tabular}

Notes: Figures in parentheses are the standard errors: ${ }^{\text {a }}$ Significant at the 10 percent level, ${ }^{\mathrm{b}}$ Significant at the 5 percent level and ${ }^{\mathrm{C}}$ Significant at the 1 percent level.

These findings indicate the importance of promoting STI to achieve green growth and sustainable development. This considers the importance of energy use, the decoupling of carbon dioxide emissions, and the promotion of forest and natural resources as key elements to achieving sustainable development, especially in developing countries where more research, investments and policies are necessary to promote green growth and development that prioritizes biodiversity and natural resource conservation. Fig. 3 summarizes the results 
of this study, indicating the relationship with some dimensions of green growth, the sustainable development actions suggested by [44] and the developed models.

\section{Conclusions}

This study analysed the relationship between green growth and STI across Colombian departments from 2005-2017 using two dynamic models through GMM estimation. The applied tests demonstrated that the methods selected in this research generated consistent, robust and reliable estimates that can be applied to evaluate the relationship between green growth and STI to achieve sustainable development.

\begin{tabular}{|c|c|c|}
\hline $\begin{array}{l}\text { The natural } \\
\text { asset base }\end{array}$ & $\begin{array}{l}\text { - Forest and biodiver sity protection } \\
\text { - Respon sible use of natural resources } \\
\text { - Strategies ba sed on kn owledge to protect and maint ain environmental } \\
\text { resources and decrea se pollution }\end{array}$ & \\
\hline $\begin{array}{l}\text { The environmental } \\
\text { and resource } \\
\text { productivity of } \\
\text { economy }\end{array}$ & $\begin{array}{l}\text { - Resource productivity based on STI } \\
\text { - High er investments in STI to prom ote environmental protection and } \\
\text { efficient use of natural resources } \\
\text { - The decoupling betw een growth, carbon dioxide emissions and en ergy } \\
\text { consumption }\end{array}$ & $\begin{array}{l}\text { To achieve } \\
\text { Green } \\
\text { Growth and }\end{array}$ \\
\hline $\begin{array}{l}\text { Economic } \\
\text { opportunities and } \\
\text { policy responses }\end{array}$ & $\begin{array}{l}\text { - Energy efficiency based on innovation and new knowledge } \\
\text { - Investments in science, technology and innovation activities (training, } \\
\text { managem ent, R\&D, etc.) } \\
\text { - Policies to promote adequate use of natural resources and prevent } \\
\text { deforestation and pollution } \\
\text { - New strategies to decrease green gas emissions to migrate a low carbon } \\
\text { economy }\end{array}$ & Development \\
\hline
\end{tabular}

Fig. 3. Results and relationship with green growth and sustainable development.

The results of the two proposed models indicate that deforestation over time can be explained by the occurrence of different events that could increase or decrease under new regulations or economic events. Investments in R\&D, STI education and STI management have negative signs and significant effects on green growth, indicating that to achieve sustainable development, it is important to promote STI throughout the value chain from education and investments to management.

Patent applications and published papers on environmental topics have negative effects on deforestation growth, demonstrating that new knowledge promotes green growth. Energy and forest variables are important to decrease the deforestation rate and promote green growth and a low carbon economy, which implies the importance of policy instruments that promote the efficient use of energy and the protection of forest and natural resources.

The results provide several policy implications with regard to energy conservation, the efficient use of resources, the reduction of pollution, and the importance of increasing research on consumption patterns in countries such as Colombia according to their own natural resources and biodiversity. It is important to formulate and frequently measure the STI indicators related to green growth and SDGs from a baseline that allows competitiveness and productivity improvements to be analysed from a sustainable development perspective and to be compared with the results from other countries. The findings of this study indicate that investments in STI and the generation of knowledge from patents and papers are important drivers decreasing the deforestation rate and promoting green growth. Further research is needed, especially in developing countries, to determine the main drivers of green growth based on STIs. 


\section{REFERENCES}

[1] Indrawati, M. Why green development is so important. [Online]. [Accessed 25.06.2019]. Available: https://www.weforum.org/agenda/2015/07/why-green-development-is-so important/

[2] ADB, ESCAP, UNEP. Green Growth, Resources and Resilience: Environmental Sustainability in Asia and the Pacific. [Online]. [Accessed 15.05.2019]. Available: http://www.adb.org/publications/green-growth-resources-and-resilience

[3] World Bank. Inclusive Green Growth: the Pathway to Sustainable Development. The World Bank. [Online]. [Accessed 10.06.2019]. Available: http://siteresources.worldbank.org/ EXTSDNET/Resources/Inclusive Green_Growth_May_2012.pdf

[4] OECD. Putting green growth at the heart of development. OECD green growth studies. OECD publishing. [Online]. [Accessed 2.06.2019]. Available: https://www.oecd.org/dac/environmentdevelopment/Putting\%20Green \%20Growth\%20at $\% 20$ the $\% 20$ Heart $\% 20$ of $\% 20$ Development_Summary $\% 20$ For $\% 20$ Policymakers.pdf

[5] OECD. OECD Work on green growth. [Online]. [Accessed 24.06.2019]. Available: http://www.oecd.org/ greengrowth/GG_Brochure_2015.pdf

[6] OECD. Green Growth and Developing Countries. A Summary for Policy Makers. [Online]. [Accessed 08.08.2019]. Available: https://www.oecd.org/dac/50526354.pdf

[7] Statistics Netherlands. Sustainable development and green growth: Comparison of the measurement frameworks at Statistics Netherlands. [Online]. [Accessed 12.09.2019]. Available: https://www.cbs.nl/-/media/.../2013-nota-dzh-ggmrt2013.pdf

[8] Juan F., Gallaghen P. Greening Development Lending in the Americas: Trends and Determinants. Ecological Economics 2018:154:189-200. https://doi.org/10.1016/j.ecolecon.2018.07.009

[9] Jouvet, P., Perthuis, C. Green Growth: From Intention to Implementation. International Economics 2013:134:29-55. https://doi.org/10.1016/j.inteco.2013.05.003

[10] Smith K., Utting P., Cook S. Green Economy or Green Society? Contestation and Policies for a Fair Transition. UNRISD produced in collaboration with the Friedrich-Ebert-Stiftung, 2012.

[11] Hallegate S., Heal G., Fay M., Treguer D. From growth to green growth - a framework. Policy research working paper 5872. The World Bank, 2011. https://doi.org/10.1596/1813-9450-5872

[12] Li D., Zheng M., Cao C., Chen X., Ren S., Huang M. The impact of legitimacy pressure and corporate profitability on green innovation: evidence from China top 100. Journal of Cleaner Production 2017:141:41-49. https://doi.org/10.1016/j.jclepro.2016.08.123

[13] Hojnik J., Ruzzier M. What drives eco-innovation? A review of an emerging literature. Environmental Innovation and Societal Transitions 2016:19:31-41. https://doi.org/10.1016/j.eist.2015.09.006

[14] Cuerva M. C., Triguero-Cano A., Corcoles D. Drivers of green and non-green innovation: empirical evidence in Low-Tech SMEs. Journal of Cleaner Production 2014:68:104-113. https://doi.org/10.1016/j.jclepro.2013.10.049

[15] Horbach J., Oltra V., Belin J. Determinants and specificities of ecoinnovations compared to other innovations and econometric analysis for the French and German industry based on the community innovation survey. Industry Innovation 2013:20(6):523-543. https://doi.org/10.1080/13662716.2013.833375

[16] Klewitz J., Zeyen A., Hansen E. G. Intermediaries driving eco-innovation in SMEs: a qualitative investigation. European Journal Innovation Management 2012:15:442-467. https://doi.org/10.1108/14601061211272376

[17] Scott A., McFarland W., Seth P. Research and Evidence on Green Growth. The Overseas Development Institute for Evidence on Demand, 2013. https://doi.org/10.12774/eod hd064.july2013.scott

[18] Glachant M. Greening Global Value Chains: Innovation and the International Diffusion of Technologies and Knowledge. OECD Green Growth Papers, OECD. [Online]. [Accessed 19.10.2019]. Available: http://www.oecdilibrary.org/docserver/download/5k483jn87hnv.pdf? Expires $=1374608206 \&$ id=id\&accname $=$ guest\&checksum=61D3E3DEF8EE9290C3FD0BBC9082EEC8

[19] Dercon S. Is green growth good for the poor? Policy research working paper 6231. The World Bank, 2012. https://doi.org/10.1596/1813-9450-6231

[20] Ploeg R., Withagen C. Green Growth, Green Paradox and the global economic crisis. Environmental Innovation and Societal Transitions 2013:6:116-119. https://doi.org/10.1016/j.eist.2012.11.003

[21] Cai W., Wang C., Chen J., Wang S. Green economy and green jobs: Myth or reality? The case of China's power generation sector. Energy 2001:36(10):5994-6003. https://doi.org/10.1016/j.energy.2011.08.016

[22] Reilly J. Green growth and the efficient use of natural resources. Energy Economics 2012:34(S1):S85-S93. https://doi.org/10.1016/j.eneco.2012.08.033

[23] Merino A., Baldi M., Gunderson I., Oberle G. Articulating natural resources and sustainable development goals through green economy indicators: a systematic analysis. Resources, Conservation \& Recycling 2018:139:90-103. https://doi.org/10.1016/j.resconrec.2018.07.007

[24] National Department of Planning. CONPES 3934 Policy of Green Growth. [Online]. [Accessed 15.09.2019]. Available: https://colaboracion.dnp.gov.co/CDT/Conpes/Económicos/3934.pdf 
[25] OECD. Environmental Performance Review. Colombia. [Online]. [Accessed 07.04.2020]. Available: https://www.oecd.org/countries/colombia/Colombia\%20Highlights\%20english\%20web.pdf

[26] National Planning Department, National Developmen Plan 2018-2022. [Online]. [Accessed 07.04.2020]. Available: https://colaboracion.dnp.gov.co/CDT/Prensa/Resumen-PND2018-2022-final.pdf

[27] Arellano M., S. Bond. Some Tests of Specification for Panel Data: Monte Carlo Evidence and an Application to Employment Equations. Review of Economic Studies 1991:58(2):277-297. https://doi.org/10.2307/2297968

[28] Arellano M., Bover O. Another Look at the Instrumental Variable Estimation of Error-Components Models. Journal of Econometrics 1995:68:29-51. https://doi.org/10.1016/0304-4076(94)01642-D

[29] Blundell R., Bond S. Initial Conditions and Moment Restrictions in Dynamic Panel Data Models. Journal of Econometrics 1998:87:115-143. https://doi.org/10.1016/S0304-4076(98)00009-8

[30] Anderson T., Hsiao C. Estimation of dynamic models with error components. Journal of the American Statistical Association 1981:76(375):29-52. https://doi.org/10.1080/01621459.1981.10477691

[31] OECD. What is green growth and how can it help deliver sustainable development? [Online]. [Accessed 07.04.2020]. Available: http://www.oecd.org/greengrowth/whatisgreengrowthandhowcanithelpdeliversustainabledevelopment.htm

[32] Lauka D., Slisane D., Ievina L., Muizniece I., Blumberga D. When Bioeconomy Development Becomes a Biomass Energy Competitor. Environmental and Climate Technologies 2018:23(3):347-359. https://doi.org/10.2478/rtuect2019-0100

[33] OECD. OECD Green Growth Studies: Energy. [Online]. [Accessed 30.11.2019]. Available: http://www.oecd.org/green growth/greening-energy/oecdgreengrowthstudiesenergy.htm

[34] OECD. Towards Green Growth. [Online]. [Accessed 10.12.2019]. Available: http://www.oecd.org/greengrowth/towards-green-growth-9789264111318-en.htm

[35] Blumberga D., Chen B., Ozarska A., Indzere Z., Lauka D. Energy, Bioeconomy, Climate Changes and Environment Nexus. Environmental and Climate Technologies 2019:23(3):370-392. https://doi.org/10.2478/rtuect-2019-0102

[36] Hultman N., Eis J., Sierra K. International actions to support green growth innovation goals. Global Green Institute and Brookings Institute. [Online]. [Accessed 05.1.2019]. Available: https://www.brookings.edu/wpcontent/uploads/2016/06/06_international_actions_green_growth_innovation.pd

[37] Green Growth Knowledge Platform. The Second Green Growth Knowledge Platform Conference: Main Outcomes, 4-5 April 2013, Paris.

[38] Diaz F., Cilinskis E. Use of Multi-Criteria TOPSIS Analysis to Define a Decarbonization Path in Colombia. Environmental and Climate Technologies 2019:23(3):110-128. https://doi.org/10.2478/rtuect-2019-0083

[39] Sierra K., Hultman N., Carlock G. Energy and green growth: recasting the options, re-envisioning sustainability. Global Economy and Development at Brookings. [Online]. [Accessed 05.1.2019]. Available: https://www.brookings.edu/research/energy-and-green-growth-recasting-the-options-re-envisioning-sustainability/

[40] Blumberga D. Mandatory Procurement Lessons. Phenomena of External Initiator Factor. Environmental and Climate Technologies 2019:23(1):188-213. https://doi.org/10.2478/rtuect-2019-0013

[41] Ocampo J. A. The macroeconomics of the green economy. The Transition to a Green Economy: Benefits, Challenges and Risks from a Sustainable Development Perspective. United Nations Division for Sustainable Development, New York, USA, 2011.

[42] LCS.RNET, 2015. COP21-A Moment of Truth for Climate and Sustainable Development, Paris.

[43] Lee D. The forest sector's contribution to a 'low carbon, green growth' vision in the Republic of Korea. Unasylva. 2012:239(63):9-16.

[44] OECD. Green Growth Indicators 2014, OECD Green Growth Studies, OECD Publishing. [Online]. [Accessed 08.04.2020]. Available: http://www.oecd.org/env/indicators-modelling-outlooks/green-growth-indicators-20139789264202030-en.htm 